\title{
What does Matthew Say about Divine Recompense? On the Misuse of the Parable of the Workers in the Vineyard (20.1-16)
}

\author{
Nathan Eubank \\ Notre Dame Seminary
}

\begin{abstract}
Discussions of the parable of the workers in the vineyard (Mt. 20.1-16) tend to rely on two key assumptions: (1) the parable eliminates 'merit' and replaces it with 'grace'. (2) The parable is the hermeneutical key to all of Matthew’s other discussions of rewards, if not the entire New Testament. This article challenges these assumptions and offers a reassessment of divine recompense in Matthew. Mt. 19.16-20.16 does not set aside 'merit' in place of 'grace' but contrasts generous wages faithfully repaid by God with even more generous wages. The Gospel as a whole emphasizes that disciples must earn treasure in heaven and forgive others their debts to enter the kingdom; those who refuse to work and who refuse to forgive will be damned. At the same time, however, God's repayment of deeds is not according to strict desert, but goes far beyond what workers have earned.
\end{abstract}

\section{Keywords}

Grace, Matthew, merit, recompense, rewards, workers in the vineyard

Discussions of the parable of the workers in the vineyard (Mt. 20.1-16) tend to rely on two key assumptions: (1) the parable radically challenges the idea that righteous deeds receive corresponding recompense from God. That is, the parable undoes the notion of 'merit' which is found in many early Jewish texts and warns disciples not to hope for rewards from God. (2) The parable is the center of Matthew's teaching about rewards. In other words, it is both the clearest articulation of what Matthew has to say on the subject and the hermeneutical key to all of Matthew's other discussions of rewards, if not the entire New Testament. The purpose of this article is to challenge these assumptions and to offer a more accurate description of divine recompense in Matthew. I argue that Mt. 19.16-20.16 does not set aside 'merit' in place of 'grace' - as I demonstrate, the very language of grace and merit is of dubious value for 
describing Matthew's theology - but contrasts generous wages faithfully repaid by God with even more generous wages. The Gospel as a whole emphasizes that one must do what God commands and earn treasure in heaven to enter the kingdom and that this repayment of deeds is fabulously generous.

\section{Part I: the role of the parable in New Testament Scholarship}

In 1963 Günther Bornkamm explained the consternation of many New Testament scholars when faced with the 'wage-thinking' (Lohngedanken) of the New Testament. Bornkamm is refreshingly candid, and his remark is worth quoting at length:

We find ourselves with a marked bias against the idea of wage [or 'reward'] in the New Testament. Educated in the Kantian conception of duty [Pflicht], we immediately connect with the idea of wage the prospect of a debased eudaemonism that clouds the purity of a moral ethos. The idea of wage in ethics, so it is said, makes people's deeds dependent on extrinsic ends. The human will can no longer govern freely only by the suitability of its maxims. It strains after the outcome of its actions and no longer does the good for its own sake. The idea of wage is opposed to the high ideal, on which Plato, the Stoics, and Idealism agree, that justice is its own wage. Hence our moral misgivings against the idea of wage. The role played by the idea of wage in Catholic teaching on morals and justification strengthens our aversion to it even more. The concept of wage sanctions the concept of merit, and indeed, as it seems, with an undeniable logical consistency. For what can the concept of wage mean other than the payment that is due for work done? Do not wage and effort, wage and merit belong together in an indestructible relationship, so that whoever says the one [sc. 'wage'] must also say the other [sc. 'merit']? And do not late Judaism and Catholicism, with their doctrine of the merit of good works, take the concept of 'wage,' which the Bible of the Old and New Testaments offers to them, just at its word? And do they not have the courage to draw out the implications for ethics and the doctrine of justification?... Hence our religious misgivings against the idea of wage $(69-70){ }^{1}$

\footnotetext{
${ }^{1}$ All translations are my own unless otherwise noted.
} 
Kant's conception of duty has cast a long shadow over studies of wage in the New Testament. ${ }^{2}$ For Kant, duty cannot be based on anything hypothetical or contingent, such as the promise of some happy outcome. ${ }^{3}$ No deed can be virtuous unless it is stripped of the 'trappings of reward or self-love' (1925: 426). In 1950 Bo Reicke noted that earlier generations of scholars were so influenced by Kant that they tended to deny the New Testament said anything at all about rewards; twentieth-century scholars, while less apt to deny outright the existence of rewards in the New Testament, still faced 'great problems as to how this reward should be conceived' (196). As we shall see, the parable of the workers in the vineyard has played a pivotal role in dealing with these 'great problems'.

For instance, Strack and Billerbeck devote a chapter to the parable of the workers in the vineyard and its significance for understanding the contrast between the New Testament teaching on wage and that of ancient Judaism (1928: 4.484-500). Jews thought humans could do meritorious deeds that God would reward, but Jesus taught that one must leave behind every thought of reward and simply do one's duty. The remark of the landowner in 20.15 to the grumbling workers shows that:

Work for God's kingdom does not proceed on the basis of a legal agreement between God and humans, so that the divine wage would correspond to human achievement, but rather the work is simply the duty of humans to be done without any regard for wages... This is the cornerstone and headstone of the New Testament teaching on wages, which is closely related to the New Testament teaching on justification (1922: 485).

The parable thus shows that for Christianity 'the question of rewards plays no role’ (1922:485). ${ }^{4}$ Strack and Billerbeck do not explain why the parable of the workers in the vineyard is the key to the entire 'New Testament teaching on reward' in contrast to Judaism. It is treated as selfevident. And while detailed exegesis of the parable must wait until below, it is worth noting that the drama of the parable springs from the fact that those who were paid a standard wage for their

\footnotetext{
${ }^{2}$ E.g., Baur 1864: 60-3. See Luz 1985-2002: 3.144 on Kant’s influence on the interpretation of Mt. 20.1-16.

${ }^{3}$ Duty is 'eine Nötigung zu einem ungern genommenen Zweck' (1907: 386). And again, 'Wir haben soviel also wenigstens dargetan, dass, wenn Pflicht ein Begriff ist, der Bedeutung und wirkliche Gesetzgebung für unsere Handlungen enthalten soll, diese nur in kategorischen Imperativen, keineswegs aber in hypothetischen ausgedrückt werden könne’ (1925: 425).

${ }^{4}$ See also the similar argument of W. O. E. Oesterley (1938: 104-105).
} 
work are offended by the master's decision to pay those who were hired late in the day more than they deserve. The scandal, in other words, is in the master's decision to be generous to those who had not worked the whole day; there is little to suggest that the workers are to forget the very concept of payment in favor of duty which is its own reward. ${ }^{5}$

The history of scholarship since Strack and Billerbeck reveals more of the same. In the essay cited above, Bornkamm uses the parable to solve the problem of the New Testament's apparent endorsement of merit, arguing that the parable's depiction of divine generosity represents the final separation of wage-thinking (Lohngedanken) and merit-thinking (Verdienstgedanken) (1963: 88). Herbert Preisker placed a special emphasis on the workers in the vineyard in his article on $\mu 1 \sigma \theta$ ó in TDNT. Jesus did speak of 'wages,' Preisker admits, but the parable shows that in fact 'the Jewish concept of merit is radically removed from the preaching of Jesus' (4.717). Jesus spoke of 'wages' only to free himself from these Jewish ideas (4.725). Bo Reicke cites the parable to argue that - despite the wage-language of the NT - ' $\ldots$..the New Testament must be said to import a Copernican reversion of all other moral systems. According to New Testament teaching, it is not man's due to claim a certain reward for his work in the service of God' (1950: 197). Jeremias lauded the parable as a setting aside of merit and law in favor of grace and gospel (1954: 138). ${ }^{6}$ Dan Via similarly reads it a condemnation of merit (1967: 152-55). In his 1966 Novum Testamentum article, 'The Conception of Reward in the Teaching of Jesus', G. de Ru focuses almost exclusively on the parable of the workers in the vineyard and concludes:

Service 'for reward' is decisively rejected by Jesus. In that sense Kant and Idealism were right, when, because of their rigorous conception of 'duty', they connected with the 'conception of reward' the idea of an inferior eudaemonism, that defaces the purity of true morality. Everything that is done with an eye to a reward is egotistic, a residue of hedonism. ... A good deed brings its own reward. As the well-known aphorism of Kant has it. 'Die Eudamonie ist die Euthanasie aller rechten Sittlichkeit’ (1966: 202).

\footnotetext{
${ }^{5}$ Heinemann (1948: 85-9) offers a very brief but incisive refutation of Strack and Billerbeck's exegesis as well as of their treatment of rabbinic literature.

${ }^{6}$ According to Jeremias, the parable shows the differences between two worlds: 'Dort Verdienst, hier Gnade; dort Gesetz, hier Evangelium’ (1954: 138).
} 
Again, it is simply assumed that this parable is hermeneutically supreme and that it is radically non-Jewish.

Since the 1970s scholars have been less likely to contrast Jesus' teaching to Judaism or to cite Kant, but when 'rewards' in Matthew are discussed, the assumptions that the parable eliminates merit and that it is the center of Matthew's Lohngedanken continue to come to the surface. ${ }^{7}$ For instance, Bernard Brandon Scott argues that the parable 'radically subverts the kingdom of God as a reward for a faithful and just life' (1989: 298). ${ }^{8}$ For Arland J. Hultgren, the parable 'drives a wedge between two ways of thinking about the Christian life...The first way is centered on human effort, goodness, and working for the kingdom of God'. The other affirms that people are saved 'purely by God's own grace' (2000: 42-43). In his 2007 commentary, R. T. France wrote the following about Matthew 6.19-20:

The verb 'store up for yourselves' ... might suggest that these heavenly treasures are to be earned by the disciples' own efforts, and the frequent language of 'reward' in this gospel easily conveys the same impression...[I]n 19:21 it is by giving to the poor that 'a treasure in heaven' is to be secured; in 19:29 eternal life is spoken of as compensation for earthly losses, and in 25:21, 33, 34, 46 the heavenly rewards are directly linked to the disciples' use of earthly opportunities. But while the theme of reward is important in this gospel, we must remind ourselves again that in the parable which most directly addresses the issue (20.1-15) there is a deliberate discrepancy between the effort expended and the recompense received. God does not leave anyone unfairly treated, but his grace is not limited to human deserving. In a kingdom in which the first are last and the last first (19:30; 20:16) there is no room for computing one's 'treasures in heaven' on the basis of earthly effort. Those treasures are ‘stored up’ not by performing meritorious acts (and certainly not only by almsgiving) but by belonging to and living by the priorities of the kingdom (258-59). ${ }^{9}$

\footnotetext{
${ }^{7}$ Charette 1992 and Luomanen 1998 are exceptions.

${ }^{8}$ See also Blomberg 1992: 159-72.

${ }^{9}$ Emphasis added.
} 
Few would quibble with France's contention that, for Matthew, God's 'grace' is not limited to human deserving - though the language of 'repayment' would better fit the Matthean idiom. ${ }^{10}$ Nevertheless, like most scholars who comment on reward in Matthew, France provides no rationale for his claim that the parable of the workers in the vineyard is the lens through which all the other passages - including the programmatic Sermon and the climactic 24.1-25.46 - must be read. ${ }^{11}$

Klyne R. Snodgrass has noted that '[M]ost interpreters want [the parable] to say more theologically than it does' (2008: 362). Indeed, it is difficult to avoid the suspicion that the parable has functioned as an interpretative deus ex machina, providing exegetes with a readymade solution to Matthew's extensive reward language - language which is obviously unpalatable to many. We turn now to assess the two assumptions that have guided this exegetical tradition, beginning with the question of whether the parable radically challenges the idea that righteous deeds receive recompense from God.

\section{Part 2: does the parable set aside divine recompense for righteous deeds?}

Matthew presents the parable as the conclusion of Jesus' words to the disciples following the departure of the rich young man. The parable is introduced in 20.1 as Jesus' expansion of his answer to Peter in 19.28-29 (o(moi/a ga/r eostin h( basilei/a tw=n ou ) ranw n...), and the parallels between the encounter with the young man and the parable further underscore this unity. The parable describes a master who is good (e@gw_a@gaqo/j ei@mi), recalling the description of God in the previous passage as 'the good one' (ei [ $j$ e@stin 09 a@gaqo/j). The parable also describes workers who toil for varying amounts of time, just as the preceding passage discusses a man who follows the commandments but is

\footnotetext{
${ }^{10} \mathrm{The} x \mathrm{x} / \mathrm{rij}$ word-group never appears in Matthew, but many passages, including the parable of the workers in the vineyard, speak of divine 'repayment'.

${ }^{11}$ Similarly problematic is France's rather oblique claim that heavenly treasure is not stored up by doing meritorious acts but by 'belonging to and living by the priorities of the kingdom'. It is not clear what 'belonging to and living by' means in contradistinction to meritorious deeds; one is left with the general impression that for Matthew heavenly treasure is not stored up by selling one's possessions and giving the money to the poor (19.21) or by any other discrete good deed, but by identifying oneself with the kingdom. Ironically, this construal is close to an inversion of 25.31-46 where it is those who did not know they were serving Jesus but who did in fact do works of mercy who receive the kingdom. That is, those who actually did 'meritorious deeds' enter into the kingdom rather than those who assume they belong (cf. also 7.21-22 and 21.28-32).
} 
unwilling to give up everything (19.18-22), contrasting him with those who do give up everything (19.27-29). Moreover, at the heart of both 19.16-26 and the parable is the question of how God will repay these different kinds of workers. The rich young man seeks eternal life but is unwilling to earn treasure in heaven. Jesus responds by saying that it is impossible for rich people to enter the kingdom, whereas those who leave possessions behind will receive a hundred times as much. Both the dramatis personae (God and those who work for God) and the central theme (divine recompense for deeds) of 19.16-26 are therefore reproduced in the parable. Moreover, Jesus concludes his response to Peter's question (19.27-30) with the words, polloil del e1sontai prw toi e1sxatoi kail e1sxatoi prw toi. Then the parable concludes ou3twj e1sontai oig e1sxatoi prw toi kail oi9 prw toi e1sxatoi (20.16), with ou3twj indicating that the parable has just demonstrated what Jesus means when he tells the apostles that the first will be last and the last will be first. A successful interpretation of the parable in its Matthean context must take the unity of 19.16-20.16 into account.

The young man seeks 'eternal life,' so Jesus tells him to obey the commandments and lists the second half of the Decalogue and Lev 19.18. The man says he has kept these but wants to know what he still lacks. Jesus responds: 'If you want to be perfect (te/leioj), go sell your possessions and give to the poor, and you will have treasure in the heavens (e3ceij qhsauro\n eon ouoranoi=j), then come, follow me. ${ }^{12}$ When the young man heard this word he went away grieving, for he had many possessions' (19.21-22). What does 'sell your possessions and give the money to the poor, and you will have treasure in the heavens' mean? The discussion that ensues after the man goes away suggests that heavenly treasure makes it possible for one to enter the kingdom.

And Jesus said to his disciples, 'Truly I say to you that it will be hard for a rich person to enter into the kingdom of the heavens. Again I say to you, it is easier for a camel to pass through the eye of a needle than for a rich person to enter into the kingdom of God'. And when the disciples heard this they were greatly astounded and said, 'Then who is able to be saved?' Looking at them Jesus said to them, 'With people this is impossible, but with God all things are possible’. (19.23-26)

\footnotetext{
${ }^{12}$ The Markan parallel (10.21) lacks the words ei@ qe/leij te/leioj e] inai, which recall Mt. 5.48.
} 
Wealth makes it all but impossible for a person to enter into the kingdom of God. Though he obeys the commandments, the young man's riches prevent him from becoming te/leioj as he should be. ${ }^{13}$

Confronted with what seems to be impossibly narrow conditions for entering the kingdom, the disciples wonder who can be saved. Jesus' reply is more suggestive than lucid: 'all things are possible with God'. Does this mean people like the rich young man can enter the kingdom? It is not clear. Jesus will return to the issue of God's generosity momentarily, but first Peter wants to know what he and the other disciples will receive for leaving everything.

Then answering Peter said to him, 'Behold, we have left everything and followed you. What then will there be for us?' Jesus said to them, 'Truly I say to you that you who have followed me, in the new age when the Son of Man sits on his throne of glory, you yourselves also will sit on twelve thrones judging the twelve tribes of Israel. And whoever left houses or brothers or sisters or father or mother or children or fields on account of my name will receive a hundred times as much and will possess eternal life. $(19.27-29)$

In return for forsaking everything the Twelve will receive not only treasure in heaven but thrones from which to rule alongside the Son of Man. Jesus then goes on to specify that this is an open offer; anyone can renounce her possessions for his sake and come to possess eternal life.

Immediately following this promise of heavenly treasure, however, Jesus adds polloi $\backslash$ de e1sontai prw toi e1sxatoi kail e1sxatoi prw toi (19.30) and tells the parable of the workers in the vineyard, a story about a 'good' master who pays the workers who worked all day a full day's wage, but who also pays the workers who were invited later the same amount. As noted above, the parable is clearly supposed to illuminate, qualify, or otherwise complement the preceding teaching. Warren Carter (1994: 127) and Charles Talbert (2010: 23839) have argued that the disciples, who have no earthly status, are 'the last' who came to work at the eleventh hour, whereas the rich young man and those like him are 'the first,' that is, those who have earthly status. According to this proposal, the parable illustrates the reversal described in 19.16-26; those with status (the rich young man) become last and those without status (the disciples) become the first. Conversely, Davies and Allison suggest the parable warns the

\footnotetext{
${ }^{13}$ He has treasure on earth with which he is not willing to part, illustrating Jesus' claim that no one can serve both God and money (cf. 6.19-24).
} 
disciples not to think they are 'the first' because they have left everything (1997: 3.67-8). ${ }^{14}$ They should not boast in their achievements because everyone will receive the same wage. Both of these lines of interpretation offer a possible reading of the parable in its context. Nevertheless, there is a significant inconcinnity in Carter and Talbert's proposal. In the parable 'the first' seem to be those who have toiled all day in the master's vineyard, and 'the last' are those who did less work. In other words, 'the first' are those who have done more work for God. It seems unlikely, then, that the 'status' of the first workers - status which is based on the fact that they toiled all day in the master's vineyard - corresponds to the 'status' that the rich man has because of his many possessions. Rather, both 19.16-26 and the parable concern the recompense due those who have done less for God (the young man and the workers hired late in the day) and those who have done more (those who have renounced their possessions and the workers hired early in the day).

Davies and Allison would seem to be nearer the mark; the parable qualifies or nuances 19.16-26 rather than simply illustrating it. It is less certain, however, that the parable functions as a warning that 'the promise of reward should not become ground upon which to stand' (Davies and Allison 1997: 3.68), or that 'It is all by grace’' (France 2000: 752). In 19.27-29 the apostles are told that they and everyone else who gives up possessions will receive a hundred times as much and will possess eternal life. Far from squelching such hopes, the parable depicts those who worked all day receiving exactly what they were promised by the master. Indeed, the payment received by those who toiled all day confirms Jesus' answer to Peter; those who do much for the master will be repaid just as they expected to be. The point of the parable can hardly be that 'everything depends on grace' since the early workers received precisely what they had earned.

I would suggest, therefore, that the primary concern of the parable is to illustrate God's generous provision for those who have done less work and to warn those who have done more not to resent this generosity. The parable confirms what 19.27-29 said about those who have earned treasure in heaven, but it picks up and develops anew a question that was left dangling in 19.23-26: what is the fate of those who have not? The rich man, like the workers who came later

\footnotetext{
${ }^{14}$ Grindheim (2008: 326) claims the parable 'functions as a rejoinder to the question of eschatological reward'. Hezser (1990: 251-89) reads the parable as a rebuke of the wandering missionaries of Matthew's day who thought they would receive a greater wage than other Christians.
} 
in the day, has done some work by keeping the commandments (19.20), but has failed to renounce his possessions. ${ }^{15}$ In response to the man's failure Jesus says it is impossible for a rich person to enter the kingdom (19.23-24). But when the astonished disciples ask, 'Who then can be saved?’ Jesus gives the reply 'With people this is impossible, but with God all things are possible' (19.26). The parable is Matthew's clarification of this point. God will faithfully repay his workers, but those who have not done enough to enter the kingdom will receive a wage that is wildly disproportionate to what they have done. Matthew does not go so far as to say the rich young man himself will necessarily be saved. The point is more generic. God will pay workers their due but will also pay those who have done less more than their due. Thus, the parable nuances but does not eliminate Verdienstgedanken; one may count on the fact that God will pay his workers what is just, but in his generosity he will also pay more than what is just - in this case paying all the workers the same wage. Indeed, 19.29 shows that even those who practice radical renunciation do not earn eternal life according to a strict accounting of deserts; rather, they will receive 'a hundred times as much' in comparison to what they left behind. ${ }^{16}$ As Heinemann put it in his 1948 riposte to Strack and Billerbeck's interpretation of the parable, 'It is the intention of the parable, then, to state that God will sometimes reward man in excess of what is his due, but certainly not to suggest that he will ever deny him his due reward' (86). ${ }^{17}$

A similar passage in 2 Baruch may illuminate the point. ${ }^{18} 2$ Baruch says that the righteous go to their deaths without fear because 'they possess with [God] a store of good works which is preserved in treasures' (14.12).$^{19}$ In the last judgment these treasuries will be opened and God will repay what is just (24:1). Yet, despite this confident assertion that heavenly treasures will enable the righteous to enter the world to come, the author goes on to say that when the treasuries are opened, 'at that time you shall see, and many with you, the long-suffering of the Most High, which lasts from generation to generation, who has been long-suffering toward

\footnotetext{
${ }^{15}$ The text gives no support for the speculation that the man's claim to keep the commandments is disingenuous.

${ }^{16}$ Thus the 'the last will be first and the first will be last' is not a strict description of reversal wherein those who have worked are deprived of what they have, but something closer to a suggestive slogan indicating a relativization of status. See the attempt to nuance the meaning of 'reversal' in Luke in Eubank 2007.

${ }^{17}$ See also Marguerat: 'Aucun des partenaires [scil. the master and the original workers] ne met en question le droit des ouvriers de la première heure à toucher leur salaire’ (1995: 459).

${ }^{18} 2$ Bar. is thought to have been written in the late first or early second century. See Klijn 1983: 1.616-17.

${ }^{19}$ Translation from Klijn 1983.
} 
all who are born, both those who sinned and those who proved themselves to be righteous' (24.2). The author does not repudiate the notion that the righteous will receive their just recompense because just recompense is not necessarily opposed to mercy in early Jewish and Christian texts. As Ps. 61.13 LXX puts it, 'To you, O Lord, belongs mercy (e1leoj), for you repay a person according to his works' ${ }^{20}$ While claiming that God repays deeds, 2 Baruch maintains that God shows himself to be long-suffering by showing mercy to both sinners and the righteous. ${ }^{21}$ These texts, like Mt. 19.16-20.16, do not repudiate the belief that God faithfully repays works, which would in any case be tantamount to claiming God is unjust or capricious (Sanders 1977: 127). Yet, God can be said to provide mercifully for those without heavenly treasures just as he mercifully repays those who do have heavenly treasures. From this angle one can see how misleading it is to characterize the parable as a setting aside of merit in favor of grace. Like 2 Baruch, the parable affirms that God will both repay those who have worked and be merciful to those who have not. 'Merit' and 'grace' exist here not as antitheses, but as varying expressions of God's faithfulness.

To sum up: in the parable of the workers in the vineyard (20.16) Jesus continues the discussion that ensued after the departure of the rich young man. In 19.16-29 two sorts of wouldbe disciples are discussed, those who leave possessions behind for Jesus thereby earning eternal life and those rich who do not. Jesus seems to say that it is all but impossible for the rich to enter the kingdom, but he also says that 'all things are possible with God' (19.23-26). Jesus then nuances this picture by telling a parable about how a master pays workers who have done different amounts of work. Those who worked all day receive the payment for which they had hoped. Those who did less surprisingly receive the same wage. The principal concern of the parable is not a warning against looking forward to one's heavenly wages - after all, the workers hired early in the day receive what they expected. Rather, the parable expands on the hint in 19.26 that God would provide for those who have worked less; in his generosity God will pay

\footnotetext{
${ }^{20}$ The MT makes the point with equal clarity: 'To you, O Lord, belongs covenant faithfulness (Tס), for you repay a person according to his works' (62.13).

${ }^{21}$ See also m. 'Avot 3.15, which is attributed to R. Akiva. 'with goodness is the world judged, and all is according to the majority of the work' (ובטוב העולם נדון והכל לפי רוב המעשה).
} 
them a wage that far exceeds what they deserve, though in so doing he will not treat the other workers unjustly (20.13).

It may be helpful to emphasize once again that Matthew does not pit 'merit' and 'grace' against one another. Rather, both 19.16-30 and 20.1-16 unabashedly promise that God will repay workers for their deeds, and this payment is itself a sign of God's generosity (19.29). The parable shows that God is free to pay his workers even more than what is just and warns those who have worked the whole day - in this context one thinks first of the disciples who left everything behind - against begrudging this generosity. ${ }^{22}$ As noted above, Matthew speaks here not of 'merit' and 'grace' but of a generous wage and an even more generous wage.

Part 3: how does the parable relate to the rest of the Gospel?

Is the parable the hermeneutical key to what Matthew says about recompense as many exegetes have assumed? In the first place, one notes that if the parable summarizes what the Evangelist wanted to say about rewards one would expect its placement in the narrative to support this function. The placement of the Sermon on the Mount at the beginning of Jesus' ministry gives it a programmatic role for the narrative as a whole, and Matthew’s final climactic block of teaching material is Matthew's most lengthy discussion of the last judgment (24.1-25.46). It would be difficult to justify a reading of the Gospel in which the parable controls all that Jesus had already said about recompense in the Sermon and all that he would say in the final block of teaching. This does not mean the parable is unimportant of course, but its placement in the narrative does cast doubt on the claim that this parable is the key to everything else Matthew says. I would like to propose three sayings $(25.29 ; 16.27$; 6.1$)$ that together summarize what Matthew says about divine recompense much more adequately than 20.1-16 alone. An exhaustive analysis of recompense in Matthew is not possible here of course, but the basic lineaments can be stated succinctly. ${ }^{23}$

The first and most important saying is 25.29: 'For to everyone who has, it will be given and he will have an abundance, but from him who does not have, even what he has will be taken

\footnotetext{
22 Though the Jew/Gentile reading of the parable must be judged secondary, an extension of the logic of the parable in this direction is in harmony with the Gospel as a whole, especially its conclusion. The Gentiles are called to work late in the day but they have been included just the same.

${ }^{23}$ For a more in-depth analysis see Eubank 2013. See also Luomanen 1998 and Charette 1992.
} 
from him'. This saying is used here as part of the conclusion to the parable of the talents. ${ }^{24}$ The parable is divided into three parts. First the master entrusts his possessions to his servants (vv.1415). The amount given to each varies according to their ability, but they all receive a fantastically high sum. Then the servants go about their business (vv.16-18), and, finally, after a long time (polu \n xro/non) the master returns to settle accounts (sunai/rei lo/gon) with them (19-30). Most commentators agree that this parable is an allegory in which the master who leaves and then returns after a long time is Jesus, and the servants represent members of the church (e.g., Davies and Allison 1997: 2.402; Beasley-Murray 1986: 215-18). ${ }^{25}$

The master praises the first two servants and promises to put them in charge of much since they were faithful with a little $(25.21,23)$. This has led some commentators to suggest that this parable shows that everyone receives the same wages regardless of the amount of work done (e.g., Luz 2002: 3.507; de Ru 1966: 218). This suggestion ignores two details, however. First, both servants earn the same rate of return on their investment - one hundred percent (France 2007: 954). It is, therefore, not surprising that they receive similarly enthusiastic responses from their master. Second, despite telling both the first and second servant that he will place them in charge of 'much,' the master does not give them identical payment for their service. In v.28 the third servant's one talent is taken from him and given to the servant with 'the ten talents,' showing that the first servant has been entrusted not only with his original five talents and the five additional talents he earned, but also this additional talent. By the end of the parable, then, the first servant has eleven talents and the second servant only four, making this parable an odd place to appeal to support the idea that all of God's workers receive the same recompense. ${ }^{26}$

The final two verses of the parable summarize its point (25.29-30). Those who work, who earn more with the master's initial investment, will be repaid generously, but those who do not earn more will lose even what they have and will be thrown into 'the outer darkness'. The fact that the 'one who has' will be given an abundance (perisseuqh/setai) shows that divine

\footnotetext{
${ }^{24}$ See also the epistemological application of this maxim in 13.12.

${ }^{25}$ Others, such as C. H. Dodd (1961:151-52) have argued that Matthew allegorized a parable that was originally directed against the Jewish leaders to address the eschatological questions of his day. N. T. Wright (1996: 632-39) argues unconvincingly that all the parables of Mt. 25 refer to the sacking of Jerusalem.

${ }^{26}$ Luke draws attention to this fact by having bystanders balk at the master's command to give yet another mina to the servant who already had ten. 'Master, he [already] has ten pounds!' (19.25).
} 
recompense goes beyond what workers earn by strict desert. It is equally clear, however, that this recompense is a generous wage for work done - a Geschenklohn (gift-wage), to borrow Luz's term - rather than a wholly unmerited gift (2002: 3.508). Indeed, the central concern of the final four verses of the parable is the unhappy fate of those who do not work.

Read in light of its context, 25.29 encapsulates three major emphases that shape everything Matthew says about divine recompense: (1) obedience is required for Jesus' disciples to enter the kingdom. It is not those who say 'Lord, Lord' who enter the kingdom, but those who do the will of the Father (7.21-23), those whose righteousness abounds (5.20), those who become te/leioj like God (5.48; 19.21), those who become like children (18.3), those who answer the invitation to the marriage feast and wear a wedding garment (22.2-14), those who take care of their fellow servants (24.45-51), those who are ready when the bridegroom comes (25.1-13), those who earn more money with the talents left by the master (25.14-23), those who feed the hungry, clothe the naked, care for the sick, and visit prisoners (25.31-40). In other words, it is those who take up their crosses and lose their lives who will find eternal life (16.24-27). (2) Correlatively, those who refuse to do what God commands are doomed. According to Matthew's portrayal of Jesus those whose righteousness does not abound, who do not become like children, who do not come to the feast, who abuse their fellow servants, who refuse to earn money with the talent left by the master, and who do not feed the hungry will be thrown into outer darkness. (3) God's repayment is very generous; salvation is not by strict desert. Those who renounce possessions receive a hundred times as much in return (19.29); those who welcome missionaries are rewarded as if they themselves were missionaries (10.40-42). Those who work only a little are paid as if they had toiled all day (20.1-16). To invoke the typology of reciprocity of Marshall Sahlins, Matthew sometimes uses images drawn from the realm of 'balanced reciprocity,' that is, reciprocity which aims for strict quid pro quo accuracy, especially when it comes to market exchange (2004: esp. 185-230). ${ }^{27}$ Yet, in Matthew the language of balanced reciprocity frequently gives way to 'generalized reciprocity,' that is, the open and less defined exchange found in families and between close friends. Payment goes far beyond what disciples deserve, and the God who repays is repeatedly called 'Father' (e.g., 5.16, 45, 48; 6.1, 4, 6, 8-9, 14-15, 18, 26, 32; 7.11, 21), and those who do his will are called 'sons' (e.g., 5.9; 5.45). Matthew does not

\footnotetext{
${ }^{27}$ E.g., Mt. 5.26.
} 
describe an anonymous, zero-sum market governed only by self-interest, then, but the eschatological recompense due to those who imitate their Father.

Matthew 25.29 also summarizes the general thrust of Matthew’s numerous sayings about the forgiveness of sins or 'debts'. Jesus teaches his followers to pray, 'Forgive us our debts (ta\ o๑feilh/mata), as we ourselves also forgive our debtors (toi=j o๑feile/taij)' (6.12). Matthew explains what this means at the conclusion of the prayer. 'For if you forgive people their trespasses (paraptw\&mata), your heavenly Father will also forgive [you], but if you do not forgive people their trespasses neither will your Father forgive your trespasses' (6.1415). God will freely forgive debts, but not for those who refuse to forgive the debts of others. ${ }^{28}$

The parable of the ungrateful servant (18.23-35) provides a vivid explanation of what this means. The kingdom is compared to a king who wanted to settle accounts with his servants. He freely forgives the unfathomably large debt of one debtor, but then discovers that this same debtor had another servant thrown into prison because he could not pay a small amount. The conclusion of the parable makes the point clear: 'And in anger his lord handed him over to the torturers until he would pay all that he owes. So my heavenly Father will also do to every one of you, if you do not forgive your brother from your hearts'. These passages follow a logic very similar to Matthew's 'reward' sayings. God is generous - in this case freely forgiving debts rather than paying wages - but those who refuse to forgive a "brother" remove themselves from God's generosity. Those who have will be given more, those who do not have - that is, those who refuse to forgive others, who refuse to work, who refuse to feed the hungry - are doomed.

We turn now to two other sayings that compliment and refine this description of recompense in Matthew. The first is in 16.27: 'For the Son of Man is about to come in the glory of his Father with his angels and then he will repay to each according to his deeds (to/te

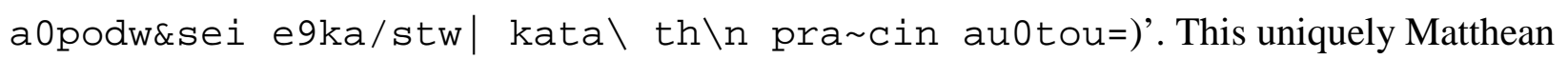
promise of impending repayment of deeds occurs in the context of Jesus' explanation that those who would follow him must deny themselves and take up their crosses.

Then Jesus said to his disciples, 'If anyone wants to come behind me, let him deny himself and take up his cross and follow me. For whoever wants to save his life

\footnotetext{
${ }^{28}$ See also 7:2b (e@n $w \mid\{\mathrm{me} / \mathrm{trw} \mid$ metrei=te metrhqh/setai u9mi=n) where the "measure" refers to measure for recording the debt of sin (Eubank 2013: 63-67; Kloppenborg 2009).
} 
$(y u x h / n)$ will lose it, and whoever loses his life $(y u x h / n)$ for my sake will find it. For what will it profit a person if he gains the whole world but forfeits his life (yuxh/n)? Or what will a person give in exchange for his life $(y u x h=j)$ ? For the Son of Man is about to come in the glory of his Father with his angels and then he will repay to each according to his deeds. (16.24-27)

It is important to note the wordplay on the two different meanings of yuxh/: present mortal life and eternal life. ${ }^{29}$ Jesus' disciples must follow him in losing their present lives to be repaid with eternal life. Using logic that is very similar to Mt. 6.19-21, v.26 explains why one should take the bold step of following Jesus in his cross-bearing: 'For what will it profit (w) felhqh/setai) a person if he gains the whole world but loses (zhmiwgh|=) his [eternal] life?' It is folly to cling to 'the world,' including one's present life, because the more precious possession is one's yuxh/ in the world to come. The next line develops this further. 'Or what will a person give in exchange (a@nta/llagma) for his [eternal] life? (16.26)'. The implied answer to this rhetorical question is, of course, 'nothing'. No matter how much earthly wealth one amasses it can never purchase eternal life. As Ps 49.7-9, a text which may have influenced this passage, puts it, ‘Truly, no ransom avails for one’s life, there is no price one can give to God for it. For the ransom of life is costly, and can never suffice that one should live on forever and never see the grave' (NRSV). In the day of judgment no one can present God with earthly treasures and purchase eternal life. ${ }^{30}$ Thus, while it may seem ridiculous to take up one's cross and give one's present life, it is in fact the more prudent course of action. No one can store up enough earthly treasure to give in exchange for one's yuxh/. It makes more sense to follow Jesus in crossbearing, to give one's life in order to find it in the resurrection (Marguerat 1995: 90-91, 99).

Unlike Mark and Luke, Matthew concludes this pericope by describing the life that cross-bearers will receive as a repayment at the Parousia: followers of Jesus should give their lives because cross-bearing is about to be repaid with eternal life. ${ }^{31}$ This uniquely Matthean

\footnotetext{
${ }^{29}$ This is an example of the ancient (and modern) rhetorical device known as antanaclasis. For other examples of antanaclasis in the synoptic tradition see Lang 2011.

${ }^{30}$ Cf. Luke 12.13-21; 17.33 .

${ }^{31} \mathrm{Mk}$ 8.38; Lk. 9.26. Although the description of eternal life as the repayment for deeds is clearer in Matthew than in the other Gospels, this idea was fairly common in early Jewish and Christian literature. See, e.g., 2 Macc 12.45; Wis 2.22; Pss. Sol. 9.5; 1 Tim 6.19.
} 
addition reflects a recurring motif of the First Gospel. Matthew repeatedly describes the coming judgment as a settling of accounts. ${ }^{32}$ For instance, in the parable of the unforgiving servant, which is found only in Matthew, the kingdom is likened to a king who wanted to settle accounts with his servants (suna rai lo/gon meta\ $t w \sim n$ dou/lwn au○tou ). The parable of the workers in the vineyard, which is also unique to Matthew, compares the eschatological payment received by Jesus' followers with a master settling accounts with his workers at the end of the day. Something similar appears in the parable of the talents (25.14-30). This parable is the penultimate pericope in the description of the last days that stretches throughout chs. 24-25.

From 24.37 on, Jesus' emphasis is on the necessity of preparing oneself for the unknown hour of the return of the Son of Man. The parable compares this to a man who entrusted his possessions to his servants before going on a journey. He returns after a long time to settle accounts with his servants. ${ }^{33}$ Matthew's addition of 16.27 summarizes all of this: cross-bearers are about to be repaid with eternal life at the Parousia.

The second saying complementing 25.29 is 6.1. 'Take care not to do your righteousness before people to be seen by them; otherwise you have (e1xete) no wage with your Father (para\tw| patri\u9mw n) who is in the heavens'. Many English translations render para\ $t w \mid \sim$ patri\ u9mw n as 'from your Father' presumably imagining repayment at the Parousia. With the dative, however, para/ does not refer to movement 'from,' but rest 'with,' 'beside,' or 'near'. As LSJ puts it, when combined with the dative, para/ denotes 'rest by the side of any person or thing, answering the question where? ${ }^{34}$ Of course, one might argue that though the Greek would be most straightforwardly translated 'with your Father,' surely the intended meaning is something like 'from your Father'. ${ }^{35}$ This is not impossible, but the verses immediately following this section suggest that 6.1 refers to a place 'with' God in the heavens. After discussing three righteous deeds (alms, prayer, and fasting) and how God will repay them

\footnotetext{
${ }^{32}$ Note the presence of to/te, a Matthean favorite (91x/Mark 6x/Luke 15x).

${ }^{33}$ Another uniquely Matthean description of the coming judgment as a settling of accounts occurs in 23.32 when the sin of the scribes and Pharisees is said to fill up the measure (to $\backslash \mathrm{me} / \mathrm{tron}$ ) of all those who have murdered the prophets throughout the centuries.

${ }^{34}$ See also BDAG.

${ }^{35}$ France (2007: 229n2) correctly notes that $\pi \alpha \rho \alpha$ with the dative can mean 'with' in the sense of 'in the judgment of'. See, e.g., Lk. 2.52.
} 
$(6.4,6,18)$, Matthew then turns to contrast earthly riches with the wealth that one accumulates with God.

Do not treasure up for yourselves treasures on earth (mh $\backslash$ qhsauri/zete u9mi=n qhsaurou $\backslash j$ eopi $\backslash \mathrm{th}=\mathrm{j} g h=j$ ), where moth and rust destroy and where thieves break in and steal. Rather, treasure up for yourselves treasures in heaven (qhsauri/zete de u9mi=n qhsaurou\j eon ou०ranw| ) where neither moth nor rust destroys and where thieves do not break in nor steal. For where your treasure is, there also will be your heart. (6.19-21)

The central question here is the location of one's treasure. Earthly riches are here today and gone tomorrow; it is far better to store one's treasure in heaven with God. This image of treasures stored up in heaven provides a highly plausible explanation of the meaning of 6.1. Matthew, like many early Jewish and Christian texts, presupposes the existence of a heavenly treasury in which the wages of righteous deeds are stored. ${ }^{36}$

Matthew 6.1, which is widely recognized to be redactional, illustrates Matthew's contrast between treasure on earth and treasure in heaven. ${ }^{37}$ In 6.1-18 Matthew distinguishes between two ways of receiving repayment for righteous deeds: immediate payment here on earth versus payment stored up in the heavens to be collected in the future. Three times $(6.2,5,16)$ Jesus repeats the same warning about those who give alms, pray, or fast for show. 'Amen I say to you, they are receiving their reward (a๑pe/xousin to $\backslash n$ misqo $\backslash n$ au०tw n)'. As Deissmann noted, aOpe/xw is a technical term used with great regularity on receipts (i.e., an aOpoxh/) in Egyptian documentary papyri (1903: 229). Acknowledgment of payment was expressed by saying 'I receive (a@pe/xw) payment, etc.' (Cf. Phil. 4.18). The sense of this thrice-repeated saying in Matthew 6 would seem to be that righteous deeds done for attention forfeit any claim to heavenly recompense. This immediate repayment from people is contrasted with future recompense from God. Three times Jesus says that God sees righteous deeds done 'in

\footnotetext{
${ }^{36}$ This also explains the present tense e1xete in 6.1 which many translations render as a future, e.g., the NAB (you will have no recompense from your heavenly Father'). See also the NIV, ESV, and CEB. For more on heavenly treasuries see Anderson 2009; Gregory 2010.

${ }^{37}$ Note the presence of Matthean vocabulary: prose/xw (Matthew 6x/ Mark 0x/ Luke 4x); dikaiosu/nh (7/0/1); misqo/j (9/1/3); e1mprosqen + a )nqrw\&pwn (5/0/1). On Matthew's contrast between heaven and earth see Pennington 2007.
} 
secret' (e@n tw $\mid \sim$ kruptw| ) and will repay them: 'Your Father who sees in secret will repay you(o( path/r sou o( ble/pwn eon tw $/ \sim$ kruptw $\mid \sim / k$ rufai/w a) podw\&sei soi)' $(6.4,6,18)$. At first glance this promise of future repayment appears to contradict Matthew’s introduction to this section in v.1 as well as vv.19-21, where payment for righteousness seems to be given in the present time. For Matthew, however, righteous deeds earn rewards which are kept in heaven until the settling of accounts when the Son of Man repays everyone for their deeds.

Matthew's contrast between earthly and heavenly riches can also be seen in the discussion following the rich man's departure in 19.27-29. In the Markan and Lukan parallels Jesus says that it is possible to enjoy one's heavenly treasure in the present life. Mark 10.30 says that those who renounce their possessions will receive a hundred times as much 'now, in the present time (nu=n eon tw $\mid \sim$ kairw $\mid \sim$ tou/tw $\mid$ ) and in the age to come eternal life (kai\eon tw| aiw ni tw| e erxome/nw| zwh \n ai@w\&nion)'. Likewise, Lk. 18.30 promises many times as much 'in this time (e@n tw $\sim \sim$ kairw $\mid \sim$ tou/tw $)$ and in the age to come eternal life (kai $\backslash$ eon $t w|\sim a i w \sim n i \quad t w| \sim e \odot r x o m e / n w \mid z w h \backslash n$ ai@w\&nion)'. In contrast, Matthew conspicuously omits any mention of recompense in the present life, preferring instead to speak only of repayment when the Son of Man returns 'in the new world' (e@n thl= paliggenesi/a|). ${ }^{38}$ This omission of any mention of recompense in the present life fits hand in glove with 6.1-21; righteous deeds earn treasure in the heavens (19.21) where they remain until the eschatological settling of accounts.

In sum: modern scholars have often claimed that divine recompense in Matthew is based on a rejection of merit and a turn to grace as articulated by 20.1-16. In place of this, I would propose the following corrections:

1. Disciples must earn treasure in heaven and forgive others their debts to enter the kingdom.

2. Those who refuse to work and who refuse to forgive will be damned.

3. Nevertheless, God's repayment of deeds is not according to strict desert, but is rather a fabulously generous Geschenklohn (gift-wage), a wage for work done that goes beyond what the worker has earned.

\footnotetext{
${ }^{38}$ On the meaning of this phrase see Sim 1993: 3-12.
} 
4. These 'wages' or 'treasures' are stored up with the Father in heaven until the Son of Man comes to 'settle accounts' and repay everyone according to their deeds.

All of these points are encapsulated by 25.29 along with 16.27 , and $6.1 .^{39}$

\section{Conclusion}

The claim that the parable of the workers in the vineyard eliminates merit and proclaims grace is untenable. Indeed, such a claim asserts a false dichotomy. All the workers respond to the invitation to work. The workers hired early in the morning receive exactly what they earned. The workers hired later in the day receive more than what they earned. The point of the parable is unlikely to be that everything depends on grace because it portrays everyone working for their wages. Neither is the parable likely to be a rebuke of those who expect recompense for their righteous deeds since the workers hired first receive exactly what they were promised. Rather than pitting merit and grace against each other, the parable contrasts payment which is expected and obvious with payment that goes far beyond what is deserved. Those who do much - in this context one thinks of the disciples and others who have left their possessions - will be faithfully repaid. But hope is not lost for those who do less. The master is free to do what he wants with what belongs to him (20.15) and will repay these workers as if they had worked the whole day. The parable thus warns the disciples not to resent God's generosity to others and clarifies Jesus' claim that salvation is attainable because 'all things are possible with God' (19.25-26). ${ }^{40}$

Similarly untenable is the claim that the parable of the workers in the vineyard is the key to all of Matthew's many discussions of divine recompense. Why should this one parable be treated as the master of dozens of other passages, including the Sermon on the Mount and Matthew's last great block of teaching material, which contains a description of the coming days and the Parousia (24.1-41), warnings to stay alert because the time of the return of the Son of Man is unknown (24.42-25.13), and which concludes with two descriptions of the last judgment (25.14-30; 25.31-46)? A more adequate summary of recompense in Matthew can be found in 25.29, along with 16.27 and 6.1. Time and again Matthew claims that it is necessary to earn treasure in heaven in order to be repaid with eternal life at the Parousia and that this repayment is fabulously generous.

\footnotetext{
${ }^{39}$ For an analysis of Matthew's description of Jesus' saving work in light of these issues see Eubank 2013.

${ }^{40}$ Cf. Lk. 15.11-32.
} 
Though the parable of the workers in the vineyard is not the key to everything Matthew says about divine recompense, it would be a mistake to conclude that the parable is at odds with Matthew's other discussions. On the contrary, the generous wage received by the workers who came late in the day is a lovely expression of Matthew's repeated claim that God will repay workers far more than they deserve. One might still object that the equal wages received by all the workers subverts the idea that divine recompense is based on obedience. If everyone receives the same payment then what real significance can there be in the call to take up one's cross in anticipation of the coming settling of accounts? Two things can be said in response. First, there is no question that the parable sits somewhat awkwardly alongside of passages in which there seem to be degrees of recompense. ${ }^{41}$ Yet, this tension becomes an outright contradiction only if the parable is read in isolation from its context and turned into a timeless depiction of how God always deals with humans. The Son of Man will either 'repay to each according to his deeds' (16.27) or he will give everyone the same payment. Both statements cannot be affirmed in abstracto. A second point builds on the first: while the parable addresses the question of whether those who have done less work can be saved, it does not discuss the fate of those who fail to do any work for the kingdom. Unlike those who do not do the will of the Father (7.21-23), the wicked tenants (21.33-43), the wedding guests who ignore the king's summons (22.1-14), or the 'goats' who do not feed the hungry etc. (25.31-46) - all of whom end up damned - the workers who came late in the day responded to the call of the master. Thus, while the parable warns against harboring resentment when God shows mercy to those who have done less work, it offers no comfort for those who would excuse themselves from working in the vineyard on the grounds that everyone will receive the same wage.

Finally, I would suggest that the words 'grace' and 'merit' are not helpful for describing Matthew's theology and should be avoided in future discussions. If 'merit' refers to something a person has earned by strict desert and if 'grace' refers to a gift from God which involves no human effort, then neither 'grace' nor 'merit' can be found in Matthew at all. ${ }^{43}$ For Matthew, God's gifts must be received with the cooperation of cruciform obedience and God's recompense for righteous deeds goes beyond strict desert. In place of a merit/grace antithesis, Matthew

\footnotetext{
${ }^{41}$ E.g., see the discussion of the parable of the talents (25.14-30) above.

${ }^{43}$ There are other ways of defining these terms of course, but this is how most commentators seem to understand them.
} 
contrasts generous wages faithfully repaid by one's Father in heaven with even more generous wages.

\section{References}

Anderson, Gary

2009 Sin: A History (New Haven: Yale University Press, 2009).

Baur, F. C.

1864 Vorlesungen über neutestamentiche Theologie (Darmstadt: Wissenschaftliche

Buchgesellschaft).

Beasley-Murray, G. R.

1986 Jesus and the Kingdom of God (Grand Rapids: Eerdmans).

Blomberg, Craig

1992 'Degrees of Reward in the Kingdom of Heaven?’ JETS 35: 159-72.

Bornkamm, G.

1963 'Der Lohngedanke im Neuen Testament', in Studien zu Antike und Urchristentum:

Gesammelte Aufsätze (2 vols.; Munich. Kaiser Verlag).

Carter, Warren

1994 Households and Discipleship: A Study of Matthew 19-20 (JSNTSup 103; Sheffield: JSOT Press).

Charette, Blaine

1992 The Theme of Recompense in Matthew's Gospel (JSNTSup 79; Sheffield: Sheffield Academic Press).

Klijn, A. F. J. 
1983 “2 (Syriac Apocalypse of) Baruch: A New Translation and Introduction,” in The Old Testament Pseudepigrapha (ed. James H. Charlesworth; 2 vols.; Garden City, NY: Doubleday), 1:615-52.

Davies, W. D. and Dale C. Allison

1988-1997 A Critical and Exegetical Commentary on the Gospel according to Saint Matthew (3 vols; ICC; Edinburgh: T\&T Clark).

Deissmann, Adolf A.

1903 Bible Studies: Contributions Chiefly from Papyri and Inscriptions to the History of the Language, the Literature, and the Religion of Hellenistic Judaism and Primitive Christianity (trans. Alexander Grieve; Edinburgh. T \& T Clark).

de $\mathrm{Ru}, \mathrm{G}$.

1966 'The Conception of Reward in the Teaching of Jesus’, NovT 8: 202-22.

Dodd C. H.

1961 The Parables of the Kingdom (New York: Scribner).

Eubank, Nathan

2007 'Bakhtin and Lukan Politics. A Carnivalesque Reading of the Last Supper in the Third Gospel', JGRChJ 4: 32-54.

Nathan Eubank

2013 Wages of Cross-Bearing and Debt of Sin: The Economy of Heaven in Matthew's

Gospel (BZNW, 196; Berlin/Boston: Walter de Gruyter).

France, R. T.

2007 The Gospel of Matthew (NICNT; Grand Rapids: Eerdmans).

Gregory, Bradley C.

2010 Like an Everlasting Signet Ring: Generosity in the Book of Sirach (Deuterocanonical and Cognate Literature Studies 2; Berlin: Walter de Gruyter \& Co.).

Grindheim, Sigurd

2008 'Ignorance is Bliss: Attitudinal Aspects of the Judgment according to Works in Matthew 25:31-46’, NovT 50: 313-31.

Heinemann $\mathrm{H}$.

1948 'The Conception of Reward in Mat. XX. 1 16', JJS 1: 85-9.

Hezser, Catherine 1990 Lohnmetaphorik und Arbeitswelt in Mt 20,1-16 (NTOA 15; Göttingen: Vandenhoeck \& Ruprecht).

Hultgren, Arland J. 
2000 The Parables of Jesus: A Commentary (Grand Rapids: Eerdmans).

Jeremias, Joachim

1954 Die Gleichnisse Jesu (Göttingen: Vandenhoeck \& Ruprecht).

Kant, Immanuel

1907 Metaphysik der Sitten (Philosophische Bibliothek 42; Leipzig: Dürr’schen).

Kant, Immanuel

1925 Grundlegung zur Metaphysik der Sitten (Philosophische Bibliothek 41; Leipzig: Felix Meiner).

Kloppenborg, John S.

2009 'Agrarian Discourse and the Sayings of Jesus: 'Measure for Measure' in Gospel Traditions and Agricultural Practices,' in Bruce W. Longenecker and Kelly D. Liebengood (eds.), Engaging Economics: New Testament Scenarios and Early Christian Reception (Grand Rapids:

Eerdmans): 104-28.

Lang, T. J.

2011 'You will desire to see and you will not see [it]': Reading Luke 17.22 as Antanaclasis,' JSNT 33: 281-302.

Luomanen, Petri

1998 Entering the Kingdom of Heaven: A Study on the Structure of Matthew's View of Salvation (WUNT 11/101; Tübingen: Mohr Siebeck).

Luz, Ulrich

1985-2002 Das Evangelium nach Matthäus (4 vols.; EKKNT; Düsseldorf: Benziger).

Marguerat, Daniel

1995 Le Jugement dans L'Évangile de Matthieu ( $2^{\text {nd }}$ ed.; MdB 6; Genève: Labor et Fides).

Oesterley, W. O. E.

1938 The Gospel Parables in the Light of the Jewish Background (London: SPCK).

Pennington, Jonathan $\mathrm{T}$.

2009 Heaven and Earth in the Gospel of Matthew (NovTSup 126; Leiden: Brill, 2007; repr. Grand Rapids: Baker Academic).

Reicke, Bo

1950 'The New Testament Conception of Reward,' in Aux sources de la tradition chréttienne:

Mélanges offerts à M. Maurice Goguel (Bibliothèque théologique; Paris: Delachaux and

Niestlé): 195-206.

Sahlins, Marshall

2004 Stone Age Economics ( ${ }^{\text {nd }}$ ed.; London/New York: Routledge). 
Sanders, E. P.

1977 Paul and Palestinian Judaism: A Comparison of Patterns of Religion (Philadelphia:

Fortress Press).

Scott, Bernard Brandon, 1989 Hear Then the Parable (Minneapolis: Fortress).

Sim, David C.

1993 'The Meaning of $\pi \alpha \lambda \imath \gamma \gamma \varepsilon v \varepsilon \sigma i \alpha$ in Matthew 19.28' JSNT 50: 3-12.

Snodgrass, Klyne R.

2008 Stories with Intent: A Comprehensive Guide to the Parables of Jesus (Grand Rapids:

Eerdmans).

Strack, H. L., and P. Billerbeck

1922-1961 Kommentar zum Neuen Testament aus Talmud und Midrasch (6 vols. Munich: C. H. Beck).

Talbert, Charles

2010 Matthew (Grand Rapids: Baker Academic, 2010).

Via, Dan O.

1967 The Parables: Their Literary and Existential Dimension (Philadelphia: Fortress Press).

Wright, N. T.

1996 Jesus and the Victory of God (Minneapolis: Fortress Press). 